\title{
Patterns of Discovery
}

N. R. HANSON

An enquiry into the conceptual foundations of science. Using historical examples, Professor Hanson investigates the logical pattern behind the finding of theories in science. 'This is a rich and exciting book, an object lesson in the fruitfulness of the marriage of the history with the philosophy of science.' Philosophical Quarterly. Cambridge Paperback, 10s. 6d. net

\section{Stories from Science, Books 3 \& 4}

A. \& A. P. D. SUTCLIFFE

The authors continue their successful series of books about famous personalities and events in the history of science, from which young people can learn a great deal of the background to scientific knowledge. Books 1 and 2 dealt with Chemistry and Physics. Book 3 covers Biology and Medicine; Book 4, Scientific Discovery and its applications in industry and everyday life. All four books are illustrated.

Books 3 \& 4, Library edition, about 12s. 6d. net; School edition, about $7 s .6 d$.

\section{Kepler's Dream}

\section{JOHN LEAR}

The full text and notes of Johannes Kepler's Somnium, Sive Astronomia Lunaris, translated into English for the first time. It describes a voyage to the moon in allegorical terms, because Kepler wished to interest fellow scientists without offending the Church. Mr Lear, who is science editor of the Saturday Review, interprets the Dream and assesses its scientific content. University of California Press. 40s. net 


\section{THE NEWCOMEN SOCIETY FOR THE STUDY OF \\ THE HISTORY OF ENGINEERING AND TECHNLOGY}

Meetings held monthly from October to April. Summer Meeting of four to five days' duration. One-day meetings in the South-East and Midlands.

Transactions, issued annually, contains seven or eight Papers. (A typical volume contained 187 pages, 40 text figures and 51 half-tone illustrations.)

Bulletin of 12 pages issued three times a year.

Subscription: 50s. (25s. without Transactions).

Apply for particulars of membership to the Hon. Secretary,

Newcomen Society,

Science Museum, London, S.W.7.

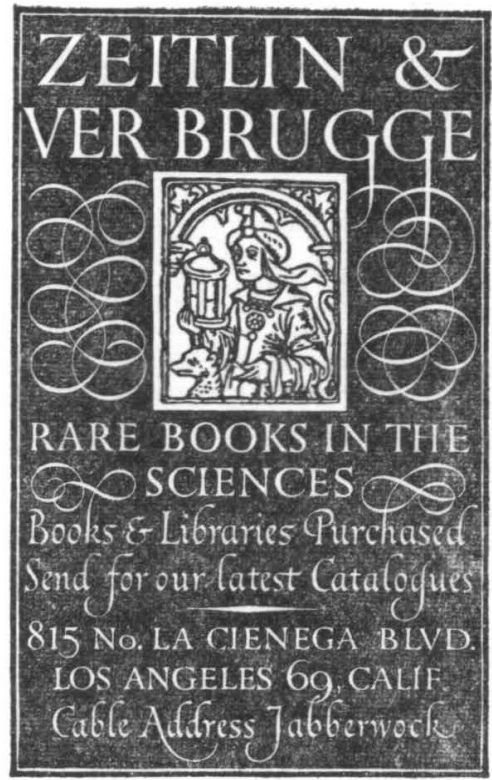

\section{BRITISH SOCIETY FOR THE HISTORY OF SCIENCE}

Programme 1965-66

Autumn Meetings-London 25 October 1965

22 November 1965

Winter Meeting-London 7.8 January 1966

Spring Meetings-London 28 March 1966

9 May 1966

Summer Meeting-Oxford 24-25 June 1966
Dr F. W. GibBs: Gunpowder Priestley and Dictionary Johnson.

Mr J. W. Herivel: Some Aspects of French Theoretical Physics in the 19th Century.

Dr A. Carugo: Galileo in England.

Dr D. S. L. Cardwell: Power, Work and Energy in the early 19th Century.

Dr M. P. Crosland: The Organization of Science in France at the beginning of the 19th Century.

The Winter Meetings will also include short reports of current research.

Dr Edwin Clarke: The early History of the Nerve Cell

Reserved for a Guest Speaker from abroad

Short papers dealing with current research. Presidential Address.

Annual Dinner 


\section{THE BRITISH SOCIETY FOR THE HISTORY OF SCIENCE}

THE objects of the Society are to further the study of the history of science, by holding meetings for the reading and discussion of papers, and by facilitating the publication of relevant material.

The British Fournal for the History of Science is the official organ of the Society.

Meetings are held in the Science Museum, Exhibition Road, South Kensington, London, S.W.7, usually in January, February, March, May, June, October and November.

Membership is open to all persons approved by the Council of the Society, and elected at an Ordinary Meeting. The annual subscription is at present $£ 2$ Ios. and includes a free issue of the Society's Journal, which appears in June and December each year.

Those who wish to join the Society should write to the Hon. Secretary, Mr. J. A. Chaldecott, Science Museum, South Kensington, London, S.W.7.

Papers for inclusion in the Journal should be submitted to the Hon. Editor, Dr. M. P. Crosland, Department of Philosophy, The University, Leeds 2, from whom instructions may be obtained concerning the presentation and documentation of papers. All communications on editorial matters, and books for review, should be addressed to the Hon. Editor.

Particulars regarding advertising in the Journal may be obtained from the Hon. Treasurer, Mr. D. Chilton, Science Museum, South Kensington, London, S.W.7.

The British Fournal for the History of Science is published by the Society. Four parts constitute one Volume; each part contains approximately 96 pages. The cover of each issue has a consecutive number for ease of collation in subsequent binding, e.g. No. 16 will be numbered: Vol. Iv Part Iv No. I6, and No. 17 will be: Vol. v Part i No. 17.

Order Forms, with lists of contents of Parts already published, are obtainable from the Hon. Publications Secretary, Mr. F. H. C. Butler, Ravensmead, Keston, Kent, to whom Orders for the Journal should be sent.

Whole Cloth Binding Cases lettered in Gold on spine and particulars of binding costs may be obtained from Headley Brothers Ltd., Invicta Press, AsHFORD, KENT. 


\section{THE BRITISH JOURNAL FOR THE HISTORY OF SCIENCE}

\section{Volume II Part III June I965 No. 7}

A. Rupert Hall-Galileo and the Science of Motion

I 85-I 99

Everett Mendelsohn-Physical Models and Physiological Concepts: Explanation in NineteenthCentury Biology

David LAYTON-Diction and Dictionaries in the Diffusion of Scientific Knowledge: an Aspect of the History of the Popularization of Science in Great Britain

K. R. and D. L. GARdiner-André-Marie Ampère and his English Acquaintances

W. E. Knowles Middleton-Jacob Hermann and the Kinetic Theory

S. I. TomkenefF-Letters from Charles Lyell and Adam Sedgwick to H. B. Tristram

Obituaries

Book Reviews 263-27 I

Books Received

Papers in Current Periodicals

Items of Interest from other Publications

Notes on Contributors

PUBLISHED BY THE BRITISH SOCIETY FOR THE HISTORY OF SCIENCE

Registered Office: Science Museum, South Kensington, London, S.W.7

Brit. J. Hist. Sci. 2 no 7. Price 15 Shillings. Free to Members of the Society. Published June I 965 